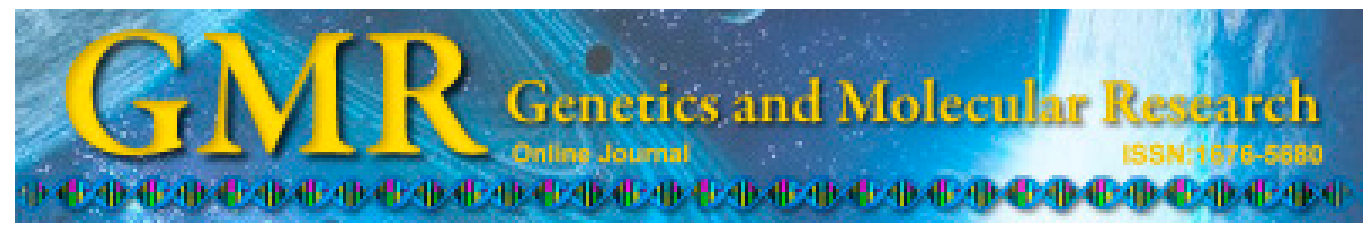

\title{
Molecular analysis and conventional cytology: association between HPV and bacterial vaginosis in the cervical abnormalities of a Brazilian population
}

\author{
A.L. Peres ${ }^{1,2}$, J.R.S.L. Camarotti ${ }^{1}$, M. Cartaxo ${ }^{3}$, N. Alencar ${ }^{3}$, R.C. Stocco ${ }^{4}$, \\ W. Beçak ${ }^{4}$, N.T. Pontes-Filho ${ }^{5}$, R.F.F. Araújo ${ }^{2,6}$, J.L. Lima-Filho ${ }^{2,6}$ and \\ D.B.G. Martins $\mathbf{s}^{2,6}$
}

${ }^{1}$ Faculdade Asces, Associação Caruaruense de Ensino Superior, Caruaru, PE, Brasil

${ }^{2}$ Grupo de Prospecção Molecular e Bioinformática, Laboratório de Imunopatologia Keizo Asami, Universidade Federal de Pernambuco, Recife, PE, Brasil

${ }^{3}$ Laboratório de Imunopatologia Keizo Asami, Universidade Federal de Pernambuco, Recife, PE, Brasil ${ }^{4}$ Laboratório de Genética, Instituto Butantan, São Paulo, SP, Brasil ${ }^{5}$ Departamento de Patologia-Centro de Ciências da Saúde, Universidade Federal de Pernambuco, Recife, PE, Brasil ${ }^{6}$ Departamento de Bioquímica-Centro de Ciências Biológicas, Universidade Federal de Pernambuco, Recife, PE, Brasil

Corresponding author: A.L. Peres

E-mail: adryaperes@hotmail.com

Genet. Mol. Res. 14 (3): 9497-9505 (2015)

Received November 14, 2014

Accepted April 6, 2015

Published August 14, 2015

DOI http://dx.doi.org/10.4238/2015.August.14.13

ABSTRACT. We investigated the association between bacterial
vaginosis (BV) and human papillomavirus (HPV) infection in
Papanicolaou smears in a Brazilian population. Cross-sectional
analysis was performed on 673 samples collected from women
attending public health centers in Olinda (PE, Brazil) by conventional 
cytology methodology and molecular analysis, PCR tests $(\mathrm{GP} 5+/ 6+$ and MY09/11). Cytological abnormalities, BV, and HPV-DNA were detected in 23 (3.4\%) samples, 189 samples (28.1\%), and 210 samples $(31.2 \%)$, respectively. GP5 $+/ 6+$ primers resulted in higher detection performance than MY09/11 primers, with $81 \%$ concordance between both primers $(\mathrm{P}<0.0001)$. The occurrence of HPV-DNA and BV had ORs of $8.59(\mathrm{P}<0.0001)$ and $2.91(\mathrm{P}=0.0089)$ for abnormal cytology, respectively, whereas the concomitant presence of both infections showed an OR equal to $3.82(\mathrm{P}=0.0054)$. Therefore, we observed an association between abnormal cervical cytology and HPV infection, $\mathrm{BV}$, or both HPV infection and BV. These results highlight the necessity of monitoring patients presenting not only HPV, but also BV, as risk factors for cervical lesion development.

Key words: Bacterial vaginosis; Human papillomavirus; Cervical intraepithelial neoplasia; Cervical cancer

\section{INTRODUCTION}

Cervical cancer is the third most common cancer in women globally, accounting for 527,624 cases in 2012 and 560,505 new cases are estimated to occur in 2015 (Ferlay et al., 2010). In Brazil, it is also the third most frequent cancer among women nationally, but increases to the second most frequent in the northeast region (INCA, 2014).

Nowadays, it is very well established that infection with specific human papillomavirus (HPV) genotypes can lead to cervical cancer, and more than $95 \%$ of cervical cancer biopsies present HPV genomes (zur Hausen et al., 2009). The viruses show a tropism for cutaneous or mucosal surfaces and can be separated into high- or low-risk types according to their oncogenic potential (Stanley, 2010).

Bacterial vaginosis (BV) is characterized by a shift from the protective Lactobacillus normally predominant in the vaginal flora to an overgrowth of anaerobic bacteria, including Gardnerella vaginalis, Atopobium vaginae, and Mobiluncus and Prevotella species. Metaanalysis has shown a positive association between BV and cervical HPV infection, and the pooled prevalence of BV can be as much as 32\% (Gillet et al., 2011, 2012). Therefore, the bacterial diversity in HPV-positive women is different and even more complex compared with HPV-negative women (Gao et al., 2013).

In this study, we investigated the possible association between BV and HPV infection in a Brazilian population (Olinda, PE) based on the cervical abnormalities in Papanicolaou (Pap) smears determined by cytopathological and molecular analysis.

\section{MATERIAL AND METHODS}

\section{Patient samples}

A cross-sectional study was carried out by sampling cervical material in public health centers in Olinda, PE, Brazil. We recruited patients aged 18-60 years from three familial health units over 2 months. The exclusion criteria were as follow: infection with HIV; pregnancy; history of 
transplant; history of partial or complete uterus removal; and treatment with immunomodulation. Cervical samples were obtained during regular gynecological inspection from the ectocervix and endocervix using a spatula and cytobrush, respectively. The material was transferred to a glass slide with a frosted end, and fixed in alcohol until required for the staining process of the Pap test. A total of 673 cervical samples were included in the present study after unsatisfactory samples had been excluded. Exclusion criteria were: lack of patient identification; broken blades; well-preserved squamous epithelial cells covering less than $10 \%$ of the blade; presence of blood or inflammatory exudates; thick areas; poor fixation; artifacts; contamination; and all other parameters that could hamper the interpretation of the sample. The Health Science Center Committee of the Universidade Federal de Pernambuco approved this research under the code CEP/CCS/UFPE 275/08. This study was conducted in accordance with the Declaration of Helsinki (1964) and the experiments were performed after collecting a signed informed consent declaration from each subject.

\section{Cytological analysis}

Cervical sample slides were transported and maintained in absolute ethanol until staining for conventional cytopathology (Shambayati, 2011). The results were categorized using the Bethesda system of nomenclature (Solomon and Nayar, 2004), as follows: negative for intraepithelial lesion or malignancy; atypical squamous cells of undetermined significance; and low- and high-grade squamous intraepithelial lesions. According to the Bethesda system nomenclature, the presence of small coccobacilli coating the surface of squamous cells (clue cells) besides the absence of lactobacillus were indicative of flora alteration and therefore suggestive of BV. The final cytological diagnoses were confirmed by the consensus of two independent cytopathologists.

\section{HPV molecular analysis}

Cervical cytobrushes were transported in phosphate-buffered saline and maintained at $4^{\circ} \mathrm{C}$ prior to DNA extraction using a Wizard Genomic Kit (Promega, Madison, WI, USA), following the manufacturer instructions. Eluted DNA was stored at $-20^{\circ} \mathrm{C}$ until required for $\mathrm{HPV}$ DNA identification, performed by polymerase chain reaction (PCR) using a GoTaq Green Master Mix (Promega, Madison, WI, USA), according to the manufacturer instructions. Two consensus primers were used for HPV-DNA amplification: GP5+/6+ (de Roda Husman et al., 1995) and MY09/11 (Manos et al., 1989). pBR322/HPV16 was used as a positive control and ultrapure water was used as a negative control. The $\beta$-actin housekeeping gene was used as a reporter to ensure the quality of DNA extraction, amplifying a region of $268 \mathrm{bp}$ (forward: 5'-AGC GGG AAA TCG TGC GTG-3' and reverse: 5'-GGT GAT GAC CTG GCC GTC-3'). PCR conditions were as follows: initial denaturation at $95^{\circ} \mathrm{C}$ for $2 \mathrm{~min}$, followed by 40 cycles of denaturation at $95^{\circ} \mathrm{C}$ for $1 \mathrm{~min}$, annealing at $62^{\circ} \mathrm{C}$ for $1 \mathrm{~min}$, and extension at $72^{\circ} \mathrm{C}$ for 1 min. The final extension step was performed at $72^{\circ} \mathrm{C}$ for $5 \mathrm{~min}$. Amplification results were observed on $1 \%$ agarose gel stained with ethidium bromide $(10 \mathrm{mg} / \mathrm{mL})$. All tests were performed twice and samples were confirmed as positive for HPV-DNA after at least two positive amplifications of GP5+/6+ or MY09/11.

\section{Statistical analysis}

Data were analyzed using the Prism statistical software (Version 6.0) calculating the 
crude ORs and $95 \%$ CIs by the chi-square test. Chi-square was considered to be statistically significant when $\mathrm{P}<0.05$. The concordance between results obtained with the two consensus primer sets was assessed by kappa statistics ( $\kappa)$ with $95 \%$ CIs using the BioEstat software (version 5.3).

\section{RESULTS}

A total of 23 samples (3.4\%) presented cytological abnormalities and BV was detected in 189 samples (28.1\%) (Table 1). HPV-DNA was detected in 210 patients $(31.2 \%)$ by PCR using consensus primers, as shown in Figure 1 . The GP5+/6+ primers presented better performance than MY09/11. One-hundred and seventy of 210 (80.1\%) infected women were detected by GP5+/6+, whereas only $123(58.6 \%)$ of the same women were detected by MY09/11. The sensitivity for detecting HPV infections was $80.95 \%$ and $58.57 \%$ for GP5+/6+ and MY09/11, respectively $(\mathrm{P}<0.0001)$. The kappa statistics revealed $81 \%$ concordance between both primer systems $(\mathrm{P}<0.0001)$.

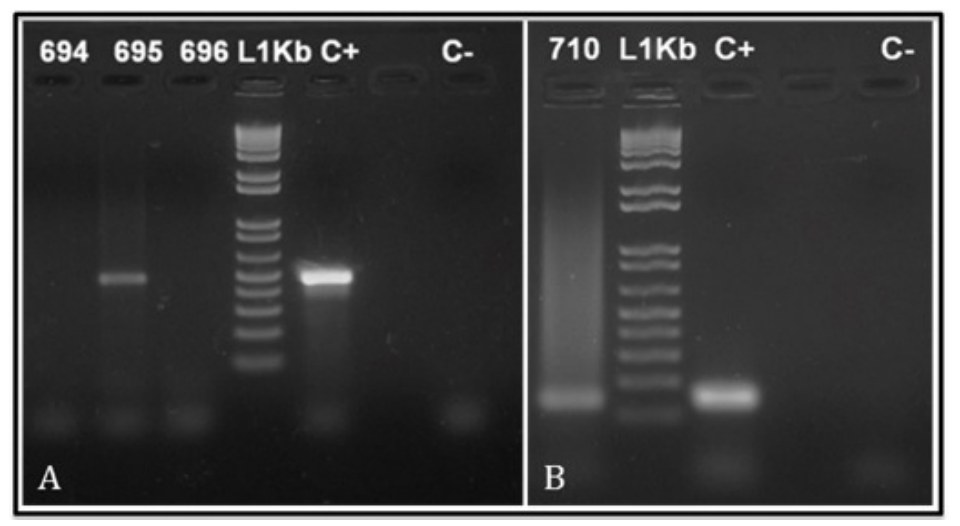

Figure 1. GP5+/6+ primers presented better performance than MY09/11. One-hundred and seventy of 210 $(80.1 \%)$ infected women were detected by GP5+/6+, whereas only $123(58.6 \%)$ of the same women were detected by MY09/11. The sensitivity for detecting HPV infections was 80.95 and $58.57 \%$ for GP5+/6+ and MY09/11, respectively $(\mathrm{P}<0.0001)$. The kappa statistics revealed $81 \%$ concordance between both primer systems $(\mathrm{P}<$ $0.0001)$.

Table 1. Occurrence of BV, abnormal cytology, and HPV DNA in the samples collected from 673 women.

\begin{tabular}{|c|c|c|c|c|c|c|c|c|}
\hline \multirow{2}{*}{$\begin{array}{l}\text { Age group } \\
\text { (Year) }\end{array}$} & \multirow{2}{*}{$\begin{array}{c}\text { Bacterial } \\
\text { vaginosis } \\
{[\mathrm{N}(\%)]}\end{array}$} & \multicolumn{3}{|c|}{$\begin{array}{l}\text { Abnormal } \\
\text { cytology }\end{array}$} & \multicolumn{3}{|c|}{ HPV-DNA identification by consensus primers } & \multirow{2}{*}{$\begin{array}{l}\text { HPV-DNA } \\
\text { Total }\end{array}$} \\
\hline & & ASC-US & LSIL & HSIL & GP5+/GP6+ & MY09/MY11 & $\begin{array}{c}\text { GP5+/GP6+ and } \\
\text { MY09/MY11 }\end{array}$ & \\
\hline$\leq 30$ & $79(41.80)$ & $3(75)$ & $10(90.9)$ & $2(25)$ & $70(41.18)$ & $55(44.72)$ & $43(51.80)$ & $82(39.05)$ \\
\hline$>30$ & $110(58.20)$ & $1(25)$ & $1(9.1)$ & $6(75)$ & $100(58.82)$ & $68(55.28)$ & $40(48.20)$ & $128(60.95)$ \\
\hline Total & 189 & 4 & 11 & 8 & 170 & 123 & 83 & 210 \\
\hline
\end{tabular}

ASC-US $=$ atypical squamous cells of undetermined significance; LSIL $=$ low grade squamous intraepithelial lesion; and HSIL = high grade squamous intraepithelial lesion.

HPV-DNA and BV were more frequent in women older than 30 years, but the difference compared with younger women was not statistically significant. Similarly, no statistical 
significance $(\mathrm{P}=0.137)$ was found when patients with $\mathrm{BV}$ and HPV-DNA present $(\mathrm{N}=67)$ were compared with those with BV and without HPV-DNA $(\mathrm{N}=122)$, despite women with BV showing a $32 \%$ higher chance of presenting HPV infection.

Presence of HPV and BV had ORs of $8.59(\mathrm{P}<0.0001)$ and $2.91(\mathrm{P}=0.0089)$ for abnormal cytology, respectively (Table 2), (Figure 2).
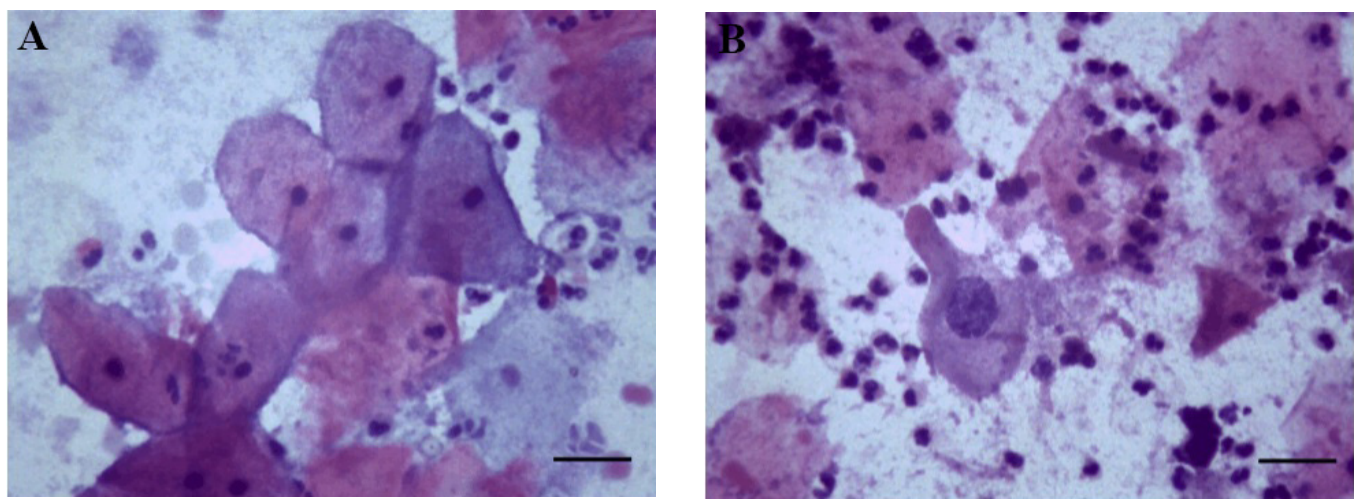

Figure 2: A. Slide showing cervical clue cells indicating bacterial vaginosis; B. dyskaryosis, characterizing lowgrade squamous intraepithelial lesion (LSIL), observed using Pap staining (bar $=10 \mu \mathrm{m})$.

Table 2. Relationship of the cytology analysis, BV, HPV DNA (molecular analysis), and infection caused by these both procedures among samples collected from 673 women.

\begin{tabular}{|c|c|c|c|c|}
\hline & \multicolumn{2}{|c|}{ Cytology } & \multirow[t]{2}{*}{$\mathrm{OR}^{\mathrm{a}}$} & \multirow[t]{2}{*}{$P$ value } \\
\hline & Abnormal (\%) & Normal (\%) & & \\
\hline \multicolumn{5}{|l|}{ HPV-DNA } \\
\hline Positive & $18(2.67)$ & $192(28.52)$ & $8.59(3.14 \text { to } 23.47)^{b}$ & \multirow{2}{*}{$<0.0001$} \\
\hline Negative & $5(0.74)$ & $458(68.05)$ & 1 (Reference) & \\
\hline \multicolumn{5}{|l|}{$\mathrm{BV}$} \\
\hline Presence & $12(1.78)$ & $177(26.30)$ & $2.91(1.26 \text { to } 6.72)^{b}$ & \multirow[t]{2}{*}{0.0089} \\
\hline Absence & $11(1.63)$ & $473(70.28)$ & 1 (Reference) & \\
\hline \multicolumn{5}{|l|}{ Lower genital tract infection } \\
\hline $\mathrm{HPV}+$ and $\mathrm{BV}$ presence & $11(1.63)$ & $56(8.32)$ & $3.82(1.41 \text { to } 10.35)^{b}$ & \multirow{2}{*}{0.0054} \\
\hline $\mathrm{HPV}+$ and $\mathrm{BV}$ absence & $7(1.04)$ & $136(20.2)$ & 1 (Reference) & \\
\hline
\end{tabular}

${ }^{a}$ Odds ratio (probability), ${ }^{\mathrm{b}} 95 \%$ confidence interval.

Furthermore, the concomitant presence of HPV and BV infection was related to cytological abnormalities $(\mathrm{OR}=3.82 ; \mathrm{P}=0.0054)$.

\section{DISCUSSION}

Susceptibility to HPV infection and impaired immune capacity may lead to infections arising from disturbances in the vaginal ecosystem and the mechanisms that protect against infections and diseases. BV may cause damage to the vaginal epithelium by degrading the cervical mucus with proteases and changing the physicochemical and immunological environment of the vaginal niche, allowing the entry of pathogens (Rodriguez-Cerdeira et al, 2012). The role of G. vaginalis, Mobiluncus, and other anaerobic microorganisms involved 
in the process of $\mathrm{BV}$ could be linked to an inhibition of neutrophil chemotaxis arising from the effects of succinic and acetic acids produced in anaerobic conditions. These acids may be important virulence factors, altering the chemotactic properties of the neutrophil or monocyte surface (Al-Mushrif et al., 2000) and influencing HPV infection.

The presence of "clue cells" suggestive of BV in samples included in this study was slightly higher than the range (14-25.6\%) reported by some Brazilian studies (Taborda et al., 2000; Buffon et al., 2006), probably due to age heterogeneity, geographical location, and socio-economic and cultural exchanges between the populations under investigation.

The frequency of HPV infection can vary according to geographical, physical, and methodological factors, as well as sample type. Our study revealed a similar percentage of HPV-DNA to studies performed in Slovenia and West Africa (Jenko et al., 2011; Piras et al., 2011). However, a higher percentage of HPV was observed in North Sardinia, Italy (35.9\%); Madrid, Spain (43.2\%); France (45.3\%); Rio Grande do Norte, Brazil (48\%); Kuwait (51\%); and Texas, USA (63\%) (Pannier-Stockman et al., 2008; Fernandes et al., 2009; Al-Awadhi et al., 2011; Martín et al., 2011; Piana et al., 2011; Shen-Gunther and Yu, 2011). In contrast, a lower percentage of infection was found in studies in Sweden (7\%) and Albania (15.1\%) (Naucler et al., 2009; Filipi et al., 2010). These studies enrolled patient numbers varying from 90 to 2400 , which may have influenced the overall values.

Two peaks of HPV infection can be observed in the female population: at the beginning of sexual age (around 23 years old); and in the middle of mature sexual age (between 30 and 45 years old) (Franco and Cuzick, 2008). In our study, positive results from the molecular test were more frequent among women over 30 years old, although no statistical significance was found. However, women under 30 years showed a higher percentage of cervical injury, which disagreed with the report describing a higher rate in patients aged over 34 years (Fernandes et al., 2009).

The combination of cytological analysis and HPV molecular testing could improve the quality of cervical screening, mainly in women older than 30 years, in whom the infection is less likely to be of a transient nature than in younger women (Franco and Cuzick, 2008). Studies demonstrate that the incorporation of testing for HPV into a screening survey for cervical cancer could reduce its incidence (Ronco et al., 2010) by earlier identification of women at high risk of this cancer (Katki et al., 2011). An HPV test is also accepted as an adjunct to cytology in primary screening for women aged 30 years or older on the basis of results from cohort studies (Naucler et al., 2009; Said et al., 2009; Selva et al., 2009; Filipi et al., 2010; Uusküla et al., 2010 ). In our study, the concordance level for cytological and molecular tests was very low compared with other studies that found up to $68 \%$ correlation (Selva et al., 2009; Martín et al., 2011). However, these differences could be related to the efficiency of the different methodologies used to identify HPV in different regions of the world.

In this field, our study evaluated two primer sets that showed good concordance, as observed by other authors (Camargo et al., 2011). However, GP5+/6+ was more efficient for HPV detection than MY09/11 in our population, in contrast to previous reports (Qu et al., 1997; Husnjak et al., 2000; Depuydt et al., 2007). This difference could have arisen because MY09/11 was designed as a degenerate primer for a conserved region of the L1 open reading frame from HPV6, HPV11, HPV16, HPV18, and HPV33 (Manos et al., 1989), which could have reduced the level of sensitivity. Otherwise, GP5+/6+ is assumed to be more capable of identifying HPV-DNA of different genotypes; it matches strongly with HPV16, but it is 
also sensitive to other genotypes such as HPV6, HPV11, HPV18, HPV30, HPV31, HPV33, HPV35, HPV39, HPV45, HPV51, HPV55, HPV59, and HPV66 (Snijders et al., 1990; de Roda Husman et al., 1995). Some authors combined the consensus primers in nested PCR, using the novel PGMY/GP+ primer set combination (Fuessel Haws et al., 2004), and modified the MY11/GP6+ PCR-based reverse-blot assay (Lin et al., 2008).

The present study showed the association between BV and HPV infection in the development of cervical lesions, in agreement with previous publications (Klomp et al., 2008; Gillet et al., 2011, 2012). In conclusion, our data indicate the relevance of taking into account $\mathrm{BV}$ and HPV presence for cervical cancer prevention. Further analysis should be performed to establish the role of specific HPV genotypes in this association.

\section{Conflicts of interest}

The authors declare no conflict of interest.

\section{ACKNOWLEDGMENTS}

The authors would like to thank Mrs. Vanessa Régia Francisco Couto and Maria Julliana Nunes for their technical support. Special thanks to Dr. Luiz Bezerra de Carvalho Júnior for his comments, suggestions, and his final review of this study. Research supported by FACEPE (grant \#APQ-0996-4.01/08).

\section{REFERENCES}

Al-Awadhi R, Chehadeh W and Kapila K (2011). Prevalence of human papillomavirus among women with normal cervical cytology in Kuwait. J. Med. Virol. 83: 453-460.

Al-Mushrif S, Eley A and Jones BM (2000). Inhibition of chemotaxis by organic acids from anaerobes may prevent a purulent response in bacterial vaginosis. J. Med. Microbiol. 49: 1023-1030.

Buffon A, Civa M and de Matos VF (2006). Avaliação de lesões intra-epiteliais escamosas e microbiologia em exames citológicos realizados em um laboratório de Porto Alegre. Rev. Bras. Anal. Clin. 38: 83-86.

Camargo M, Soto-De Leon S, Sanchez R, Munoz M, et al. (2011). Detection by PCR of human papillomavirus in Colombia: Comparison of GP5+/6+ and MY09/11 primer sets. J. Virol. Methods 178: 68-74.

Depuydt CE, Boulet GA, Horvath CA, Benoy IH, et al. (2007). Comparison of MY09/11 consensus PCR and type-specific PCRs in the detection of oncogenic HPV types. J. Cell. Mol. Med. 11: 881-891.

de Roda Husman AM, Walboomers JM, van den Brule AJ, Meijer CJ, et al. (1995). The use of general primers GP5 and GP6 elongated at their 3' ends with adjacent highly conserved sequences improves human papillomavirus detection by PCR. J. Gen. Virol. 76: 1057-1062.

Ferlay J, Shin HR, Bray F, Forman D, et al. (2010). Estimates of worldwide burden of cancer in 2008: GLOBOCAN 2008. Int. J. Cancer. 127: 2893-2917.

Fernandes JV, Meissner R de V, de Carvalho MG, Fernandes TA, et al. (2009). Prevalence of HPV infection by cervical cytologic status in Brazil. Int. J. Gynaecol. Obstet. 105: 21-24.

Filipi K, Tedeschini A, Paolini F, Celicu S, et al. (2010). Genital human papillomavirus infection and genotype prevalence among Albanian women: a cross-sectional study. J. Med. Virol. 82: 1192-1196.

Franco EL and Cuzick J (2008). Cervical cancer screening following prophylactic human papillomavirus vaccination. Vaccine 26: 16-23.

Fuessel Haws AL, He Q, Rady PL, Zhang L, et al. (2004). Nested PCR with the PGMY09/11 and GP5(+)/6(+) primer sets improves detection of HPV DNA in cervical samples. J. Virol. Methods 122: 87-93.

Gao W, Weng J, Gao Y and Chen X (2013). Comparison of the vaginal microbiota diversity of women with and without human papillomavirus infection: a cross-sectional study. BMC Infect. Dis. 13: 271. 
Gillet E, Meys JF, Verstraelen H, Bosire C, et al. (2011). Bacterial vaginosis is associated with uterine cervical human papillomavirus infection: a meta-analysis. BMC Infect. Dis. 11: 1-9.

Gillet E, Meys JF, Verstraelen H, Verhelst R, et al. (2012). Association between bacterial vaginosis and cervical intraepithelial neoplasia: systematic review and meta-analysis. PLoS One 7: e45201.

Husnjak K, Grce M, Magdić L and Pavelić K (2000). Comparison of five different polymerase chain reaction methods for detection of human papillomavirus in cervical cell specimens. J. Virol. Methods 88: 125-134.

INCA (Instituto Nacional de Câncer José Alencar Gomes da Silva) (2014). Estimativa 2014: incidência de câncer no Brasil. Ministério da Saúde, Rio de Janeiro, Brasil. Available at [http://www.saude.sp.gov.br/resources/ses/perfil/ gestor/homepage/outros-destaques/estimativa-de-incidencia-de-cancer-2014/estimativa_cancer_24042014.pdf]. Accessed February 27, 2015.

Jenko K, Kocjan B, Zidar N, Poljak M, et al. (2011). In inverted papillomas HPV more likely represents incidental colonization than an etiological factor. Virchows. Arch. 459: 529-538.

Katki HA, Kinney WK, Fetterman B, Lorey T, et al. (2011). Cervical cancer risk for women undergoing concurrent testing for human papillomavirus and cervical cytology: a population-based study in routine clinical practice. Lancet Oncol. 12: $663-672$.

Klomp JM, Boon ME, Van Haaften M and Heintz AP (2008). Cytologically diagnosed Gardnerella vaginalis infection and cervical (pre)neoplasia as established in population-based cervical screening. Am. J. Obstet. Gynecol. 199: 480.

Lin CY, Chao A, Yang YC, Chou HH, et al. (2008). Human papillomavirus typing with a polymerase chain reaction-based genotyping array compared with type-specific PCR. J. Clin. Virol. 42: 361-367.

Manos MM, Ting Y, Wright DK, Lewis AJ, et al. (1989). Use of polymerase chain reaction amplification for the detection of genital human papillomaviruses. Cancer Cells. 28: 209-214.

Martín P, Kilany L, García D, López-García AM, et al. (2011). Human papillomavirus genotype distribution in Madrid and correlation with cytological data. BMC Infect. Dis. 11: 316-320.

Naucler P, Ryd W, Törnberg S, Strand A, et al. (2009). Efficacy of HPV DNA testing with cytology triage and/or repeat HPV DNA testing in primary cervical cancer screening. J. Natl. Cancer Inst. 101: 88-99.

Pannier-Stockman C, Segard C, Bennamar S, Gondry J, et al. (2008). Prevalence of HPV genotypes determined by PCR and DNA sequencing in cervical specimens from French women with or without abnormalities. J. Clin. Virol. 42: 353-360.

Piana A, Sotgiu G, Castiglia P, Pischedda S, et al. (2011). Prevalence and type distribution of human papillomavirus infection in women from North Sardinia, Italy. BMC Public Health 11: 785-793.

Piras F, Piga M, De Montis A, Zannou AR, et al. (2011). Prevalence of human papillomavirus infection in women in Benin, West Africa. Virol. J. 8: 514-520.

Qu W, Jiang G, Cruz Y, Chang CJ, et al. (1997). PCR detection of human papillomavirus: comparison between MY09/ MY11 and GP5+/GP6+ primer systems. J. Clin. Microbiol. 35: 1304-1310.

Rodriguez-Cerdeira C, Sanchez-Blanco E and Alba A (2012). Evaluation of Association between vaginal infections and high-risk human papillomavirus types in female sex workers in Spain. ISRN Obstet. Gynecol. 2012: 240190.

Ronco G, Giorgi-Rossi P, Carozzi F, Confortini M, et al. (2010). Efficacy of human papillomavirus testing for the detection of invasive cervical cancers and cervical intraepithelial neoplasia: a randomised controlled trial. Lancet. Oncol. 11: 249-257.

Said HM, Ahmed K, Burnett R, Allan BR, et al. (2009). HPV genotypes in women with squamous intraepithelial lesions and normal cervixes participating in a community-based microbicide study in Pretoria, South Africa. J. Clin. Virol. 44: 318-321.

Selva L, Gonzalez-Bosquet E, Rodriguez-Plata MT, Esteva C, et al. (2009). Detection of human papillomavirus infection in women attending a colposcopy clinic. Diagn. Microbiol. Infect. Dis. 64: 416-421.

Shambayati B (2011). Cytopathology. Oxford, New York.

Shen-Gunther J and Yu X (2011). HPV molecular assays: defining analytical and clinical performance characteristics for cervical cytology specimens. Gynecol. Oncol. 123: 263-271.

Snijders PJ, van den Brule AJ, Schrijnemakers HF, Snow G, et al. (1990). The use of general primers in the polymerase chain reaction permits the detection of a broad spectrum of human papillomavirus genotypes. J. Gen. Virol. 71: 173-181.

Solomon D and Nayar R (2004). The Bethesda System for Reporting Cervical Cytology. 2nd edn. Springer-Verlag, New York.

Stanley M (2010). Pathology and epidemiology of HPV infection in females. Gynecol. Oncol. 117: 5-10.

Taborda WC, Ferreira SC, Rodrigues D, Stávale JN, et al. (2000). Rastreamento do câncer de colo uterino em índias do Parque Indígena do Xingu, Brasil central. Rev. Panam. Salud Publica 7: 92-96. 
Uusküla A, Kals M, Kosenkranius L, McNutt LA, et al. (2010). Population-based type-specific prevalence of high-risk human papillomavirus infection in Estonia. BMC Infect. Dis. 10: 63.

zur Hausen H (2009). Papillomaviruses in the causation of human cancers - a brief historical account. Virology 384: 260265. 